\title{
ARTUR JAZDON
}

Piotr Nowak, Cenzura wobec rynku ksiażki. Wojewódzki Urząd Kontroli Prasy, Publikacji $i$ Widowisk w Poznaniu w latach 1946-1955, Poznań: Wydawnictwo Naukowe UAM 2012, ss. 193

Recenzowaną książką Piotr Nowak powraca do realizowanej przed laty tematyki badawczej dotyczącej poznańskiego rynku wydawniczego, drukarskiego, księgarskiego. Wraca tym razem opracowaniem, które tych wskazanych powyżej problemów dotyczy... niejako pobocznie. Niejako pobocznie, bo wszyscy pamiętający nie tak dawną przecież historię Polski mają świadomość, jak ważną rolę w kształtowaniu rynku książki odgrywał tytułowy urząd. I nawet jeśli publikacja nie informuje bezpośrednio bądź wyłącznie o rozmiarach czy strukturze produkcji wydawniczej, nie charakteryzuje dorobku poszczególnych oficyn, to i tak wiemy, że to właśnie w wyniku działalności tego urzędu, realizującego wytyczne polityki państwa wobec nauki, kultury i oświaty, efekty działalności wydawniczej i księgarskiej wyglądały właśnie tak a nie inaczej.

O ile historia ruchu wydawniczego w Poznaniu okresu zaborów oraz lat międzywojennych doczekała się opracowań monograficznych ${ }^{1}$, o tyle okres pierwszych lat powojennych taką syntezą nie został objęty. Można wskazać właściwie tylko rozprawę doktorską Jerzego Ziółka, opracowanie przygotowane jeszcze $\mathrm{w}$ latach przed zmianami społeczno-polityczny$\mathrm{mi}, \mathrm{w}$ których to czasach autor musiał charakteryzować badany problem zgodnie z założonymi wytycznymi, uzupełnionymi drobniejszymi artykułami². Dlatego też problemów związanych z rezultatami działań

${ }^{1}$ Zob. A. Jazdon, Wydawcy poznańscy lat 1815-1914. Kształtowanie środowiska i repertuaru wydawniczego, Poznań 2013; P. Nowak, Poznań jako ośrodek wydawniczy w dwudziestoleciu 1919-1939, Poznań 1997.

2 Zob. J. Ziołek, Ruch wydawniczy w Poznaniu w latach 1945-1965 [maszynopis pracy doktorskiej przygotowanej pod kierunkiem prof. dr. Z. Grota], Poznań 1966; idem, Ruch wydawniczy w Poznaniu w latach 1945-1964, w: Materiaty z sesji naukowej 
cenzorskich nie można było rozpatrywać w odpowiednim świetle. $Z$ tego względu tak cenna jest publikacja Nowaka, który podjął próbę opisu i wyjaśnienia wybranych aspektów działalności cenzury prewencyjnej realizowanej przez Wojewódzki Urząd Kontroli Prasy, Publikacji i Widowisk (WUKPPiW) w Poznaniu w odniesieniu do publikacji nieperiodycznych wydanych w latach 1946-1955. Przyjęte cezury są jak najbardziej uzasadnione, gdyż omówiony okres rozpoczyna się uruchomieniem w Poznaniu przedmiotowego organu, a kończy - rokiem umownego zakończenia okresu stalinizmu. Oczywiście zwłaszcza w odniesieniu do Poznania można by zastanawiać się nad cezurą ważnego z wielu powodów roku 1956, słusznie jednak autor uwzględnił aspekt ogólnopolski. $\mathrm{W}$ ostatniej konkluzji podsumowania co prawda sam napisze, że w roku 1957 wiadomo było, że system cenzury prewencyjnej będzie nadal istniał, ale jej rola będzie inna, także ze względu na coraz ściślejszą cenzurę wewnętrzną znacjonalizowanego sektora. Może więc warto było uwzględnić ten okres w prowadzonych badaniach? Choć zapewne nie wpłynęłoby to na konkluzje.

Lektura opracowania Nowaka skłania do wyrażenia życzenia, aby ten problem został zbadany w tym samym stopniu szczegółowości dla innych ważnych ośrodków wydawniczych, co pozwoliłby przeprowadzić analizę porównawczą. Autor wskazuje we wstępie nieliczne przykłady opracowań dotyczących problematyki powojennego ruchu wydawniczego, w tym wyraźnie zwracających uwagę na pokrewne zagadnienia. Mimo więc tego, iż nie jest to publikacja pionierska w całym tego słowa znaczeniu, dokładność zbadania poruszanych zagadnień czyni ją studium niezwykle cennym i mogącym stanowić dla innych badaczy podstawę odniesień.

Autor posłużył się w pracy badawczej niewykorzystywanymi dotychczas praktycznie $\mathrm{w}$ badaniach bibliologicznych aktami WUKPPiW, zachowanymi, jak określa, w około $60 \%$. Wykorzystanie tego zespołu, jak i uzupełnienie analizy zawartych w nim materiałów pojedynczymi dokumentami rozproszonymi $w$ innych archiwach czy bibliotekach pozwalaja założyć, iż wyciągnięte wnioski są uprawomocnione i wiarygodne. Autor nie wskazuje jednak, czy w ogóle, a jeśli tak, to w jakim zakresie, dokonał analizy archiwaliów dotyczących poszczególnych wydawców bądź instytucji wydawniczych, zgromadzonych w tym samym archiwum, czy

w XX-lecie PRL, cz. 1, red. C. Łuczak, Poznań 1966, s. 177-205; J. Dydowiczowa, Ruch wydawniczy w Poznaniu w latach 1945-1950, „Kronika Wielkopolski” 1990, nr 4 (57), s. 34-42. Wspomnieć można także wcześniejsze opracowanie dotyczące księgarstwa, czyli artykuł A. Murawy, Księgarstwo w Poznaniu w latach 1945-1975, „Kronika Miasta Poznania" 1975, nr 4, s. 23-42. 
dokumentów Archiwum Archidiecezjalnego. W tym drugim wypadku jest to szczególnie ważne ze względu na rolę Poznania jako ośrodka książki religijnej - fakt podkreślony już w drugim akapicie wstępu. Analiza przypisów - szczególnie w rozdziale pierwszym - wskazuje, iż z części z tych archiwaliów autor korzystał. Nowak nie informuje nas także, w jakim zakresie przeprowadził kwerendę prasową. Mam świadomość trudności wykonania takiego zadania, wynikającej głównie z czasochłonnego przeglądania wielu tomów „Głosu Wielkopolskiego" czy "Gazety Poznańskiej", ale ciekawe byłoby ukazanie, w jakim stopniu problematyka ta znajdowała odzwierciedlenie na ich łamach. Szczególnie w pierwszych czterech-pięciu latach badanego zjawiska, a więc likwidacji prywatnego sektora wydawniczego analiza taka mogłaby być interesująca. Być może właśnie dopiero na podstawie recenzowanej książki i zawartych w niej materiałów badanie takie można podjąć.

Autor jest bibliologiem, słusznie zatem w czasie przeprowadzania badań i analiz zwracał uwagę na omawiane problemy przede wszystkim z punktu widzenia księgoznawczego. I chwała mu za to, że nie zagłębiał się $\mathrm{w}$ dokładniejsze, niż wynikało to $\mathrm{z}$ założenia badawczego, analizy społeczno-polityczne. Dzięki temu otrzymaliśmy materiał zwarty i jednorodny.

Książka ma logiczna, spójną konstrukcję. Podzielona została na pięć obszernych rozdziałów, z których każdy złożony jest z kilku-kilkunastu podrozdziałów, co bardzo ułatwia orientację w strukturze oraz odnajdowanie wybranych, interesujących czytelnika fragmentów. Całość uzupełnia podsumowanie prezentujące wiele usystematyzowanych w podgrupy wniosków, a także zespół czterech dokumentów przedstawionych w aneksie. Jak przykładna publikacja naukowa zawiera ona indeks nazwisk. Dość zastanawiający jest natomiast brak wykazu źródeł (którego nie zastępuje do końca ich skrótowa charakterystyka we wstępie) czy opracowań. Nie uzyskujemy w wyniku tych drobnych mankamentów informacji o wykorzystaniu innych materiałów źródłowych niż te dotyczące WUKPPiW.

Rozdział pierwszy, wprowadzający, autor poświęcił na scharakteryzowanie zmian dokonujących się na rynku książki, wskazując na problematykę centralizacji aparatu wydawniczego, dając krótki rys struktury ówczesnego rynku wydawniczo-księgarskiego, rezultatów osiąganych przez działające na nim podmioty, a także toczonej z nimi wiele lat „walki o handel". Kończy go podrozdział zatytułowany Cenzura, omawiający krótko przede wszystkim historię powołania urzędu centralnego w Warszawie, przyświecające jego tworzeniu założenia organizacyjne, ze zwróceniem szczególnej uwagi na zagadnienie organizacji działalności 
w terenie i współpracy centrali z właściwymi urzędami wojewódzkimi. Stanowi to bardzo dobre, logiczne przejście do omawiania tytułowego tematu, a pewna skrótowość $\mathrm{w}$ prezentacji sytuacji na rynku księgarsko-wydawniczym tych lat jest zrozumiała.

W drugim rozdziale autor przedstawił strukturę i zrelacjonował zasady funkcjonowania urzędu. Dwa pierwsze podrozdziały traktujące o strukturze terenowej i wewnętrznej oraz kadrach nie są rozbudowane. Przedstawiając problemy kadrowe, Nowak starał się scharakteryzować zespół cenzorski, słusznie wychodząc z założenia, że jednak to od ludzi, ich wykształcenia i przygotowania do pełnienia powierzonych im zadań będzie $\mathrm{w}$ dużym stopniu zależała faktyczna ich realizacja. $\mathrm{W}$ tym miejscu z żalem autor zwraca uwagę na pewne braki w dokumentacji z czym należy się zgodzić - nie pozwalają one bowiem na pełną ocenę zachowań i działań każdego cenzora. Za ważne uznał też Nowak wydzielenie odrębnego podrozdziału dotyczącego szkoleń zawodowych, ale i ideologicznych. Szczególnie bowiem te drugie miały zapewnić właściwą z punktu widzenia władz realizację zadań. Najobszerniejszy jest podrozdział omawiający zasady kontroli. Jak można się spodziewać, szkicowany obraz potwierdza, iż miejscowi urzędnicy działali zgodnie z założeniami, wytycznymi i instrukcjami płynącymi z Warszawy. Ciekawa jest natomiast już na tym etapie uwaga, iż częstokroć urząd centralny, w sytuacji rozstrzygania spraw dyskusyjnych, okazywał się mniej restrykcyjny niż poznański. W rozdziale tym autor przytacza wiele przykładów wyrażania lub nie zgody na wydanie konkretnych publikacji, co samo w sobie jest niezwykle interesujące, ale $\mathrm{w}$ niejednym przypadku mogłoby zostać przeniesione do jednego z kolejnych rozdziałów omawiających merytorycznie dany problem. Skromny tytuł podrozdziału Zasady kontroli nie wskazuje, iż dotyczy on aż w takim stopniu, jak to uczynił autor, praktyki funkcjonowania cenzorów, uzasadnień ich konkretnych decyzji, ale właśnie nakreśleniu wyłącznie organizacji procesów pracy i podstaw jej wykonywania. Rozważania kończy podrozdział odnoszący się ogólnie do statystyki działalności urzędu. Nowak zwraca uwagę na niekompletność źródeł, sugerującą braki w zestawieniu. Ciekawe jednak byłoby umieszczenie tu także informacji na temat statystyki produkcji wydawniczej w Poznaniu czy w całym województwie, która jest możliwa do sporządzenia na podstawie istniejących źródeł i opracowań. Można by wówczas ocenić, na jakim procencie całego dorobku wydawniczego - poddawanego bez wątpienia kontroli w komplecie - autor buduje konkluzje.

Kolejne trzy rozdziały poświęcone zostały omówieniu konkretnych działań cenzorskich wobec książek z trzech zasadniczych grup wydawnictw: książki naukowej, fachowej i podręcznikowej; literatury religijnej 
i literatury pięknej. Zdziwienie budzi fakt, iż dwa pierwsze rozdziały rozpoczynają się krótkim przedstawieniem międzywojennych tradycji wydawniczych Poznania oraz próby ich odbudowy po odzyskaniu niepodległości. Na marginesie dodajmy, iż we wcześniejszych partiach książki i tu nie znajdujemy uwagi autora na temat pewnej rozbieżności, być może niezasadnie przeze mnie podnoszonej. Autor pisze jednak o urzędzie obejmującym zakresem działania całe województwo, a w wielu miejscach swej analizy (także w tym dotyczącym aspektów ruchu wydawniczego) ogranicza się do Poznania, nie mówiąc, dlaczego pomija teren województwa i działających tam ośrodków wydawniczych. $\mathrm{W}$ związku z umieszczeniem $\mathrm{w}$ pracy pierwszego rozdziału o wspomnianej strukturze wewnętrznej nieuniknione jest rozbicie niektórych kwestii czy ich powtórzenie. Wydaje się, iż korzystniej byłoby przedstawić ogólny obraz sytuacji i przeobrażeń na rynku książki do 1955 roku w pierwszym rozdziale, a następne poświęcić już wyłącznie opisowi konkretnych działań. Omówienia w kolejnych rozdziałach są niezwykle interesujące dzięki temu, że Nowak przytacza mniej lub bardziej obszerne uzasadnienia sporządzone przez konkretnych cenzorów. Nie jesteśmy więc zdani wyłącznie na subiektywna ocenę autora, ale jego spostrzeżenia i podsumowania znajdują odzwierciedlenie i uzasadnienie $\mathrm{w}$ - dla nas często barwnych, interesujących, czasem nadal bulwersujących czy budzących zdziwienie - autentycznych ocenach. Analiza tych wypowiedzi wskazuje, iż ówcześni cenzorzy brali pod uwagę wiele aspektów czytanych materiałów. Oczywiście publikacje musiały być zgodne z założeniami nowego ustroju społeczno-politycznego, ale - jak podkreśla autor opracowania cenzorzy zwracali też uwagę na poprawność językową czy zbyt niski poziom merytoryczny. Trafność tych uwag nie powinna budzić w większości wypadków zdziwienia czy protestów, szczególnie gdy czytając je, wrócimy do rozdziału omawiającego sytuację kadrową urzędu. Wielu ówczesnych cenzorów znanych jest z późniejszej działalności w nauce czy kulturze poznańskiej.

Publikację zamykają wnioski na temat rezultatów działań cenzorskich. Analiza zebranego materiału pozwala raz jeszcze stwierdzić autorowi fakt systematycznego rozszerzania kryteriów kontroli zawartych w wielokrotnie nowelizowanym dekrecie z 5 lipca 1946 roku. Rozszerzenie to wynikało z bieżącego otrzymywania wielu szczegółowych wytycznych. $\mathrm{W}$ odniesieniu do publikacji naukowych $\mathrm{z}$ biegiem lat naczelna stała się dbałość o ideologiczną poprawność stosowanej metodologii badań. W sposób szczególny, trywializując założenia dialektyki marksistowskiej, tropiono rzekomy ahistoryzm, przejawy „usystematyzowanego kolekcjonerstwa", tzw. obiektywizm wykładu, zapatrzenie w naukę Zachodu. 
W wypadku braku kompetencji naukowych cenzora punktem wyjścia stawała się poprawność odwołań bibliograficznych, czyli fakt cytowania literatury radzieckiej. Autor wskazuje jeszcze na dwa charakterystyczne elementy: znaczącą rolę wydawców prywatnych w publikowaniu bardziej niezależnych myśli i zmiany na niekorzyść $\mathrm{w}$ tym zakresie wraz $\mathrm{z}$ postępującą nacjonalizacją tej sfery oraz - wspomniany już - większy liberalizm urzędu centralnego. Wskazywałoby to na słabość miejscowego „czynnika ludzkiego", który pewnie z obawy o swą przyszłość starał się być momentami "świętszy od papieża". Autor zauważa dodatkowo - co odnosi się do całej grupy zawodowej, a nie tylko do osób zajmujących się książką naukową - że cenzorzy nie byli zaangażowani ideologicznie w swoją pracę, wykonywali ją niejako automatycznie, traktowali ją zwyczajnie jako źródło utrzymania. Nie można jednak tego stwierdzenia w żaden sposób zweryfikować. Pomocne mogłyby chyba być jedynie rozmowy z byłymi cenzorami i ich ewentualna szczera ocena tego zagadnienia.

Autor podkreśla zauważalny paradoks $\mathrm{w}$ przypadku wydawnictw o tematyce religijnej. Sektor, na którego zwalczeniu najbardziej zależało nowej władzy, najlepiej przeszedł okres „walki o handel”. Jednak i w zakresie tych publikacji, dostrzegając trzy wyraźne okresy w działalności cenzorskiej, Nowak zwraca uwagę na wzrost poziomu represyjności z każdym rokiem.

Literatura piękna była natomiast według autora cenzurowana w sposób najmniej skrępowany, często według zasad wypracowanych przez cenzorów samodzielnie na własny użytek. Urzędy kontroli nie miały większego wpływu na jej wymowę ideowa, spełniały w zasadzie funkcję regulatora wewnątrzrynkowego, przyśpieszającego proces nacjonalizacji rynku przez wycofywanie konkretnych pozycji z ofert wydawców prywatnych czy spółdzielczych.

Podsumowując, otrzymaliśmy książkę niezwykle ważna, interesująca, logicznie skonstruowana, napisaną wartkim stylem, z wieloma wstawkami i cytatami, co nie tylko ubarwia język, ale i doskonale dokumentuje komentarze autora. Pracę uzupełnia bogaty materiał ilustracyjny. Mimo wskazanych drobnych uchybień publikacja skłania do myślenia i winna przyczynić się do pogłębienia badań w podjętym przez autora obszarze. 